\title{
Notes on the Littoral Polychæta of Torquay (Part II.).
}

\author{
By
}

Major E. V. Elwes.

\section{Phyllodocidæ.}

IT cannot be said that all the species of the Phyllodocidæ have yet been satisfactorily defined, much difference of opinion existing as to the separation of varieties and species. In the accompanying key the nomenclature of Professor McIntosh has been followed, but those Annelids, which are classed by him as varieties, but which have been hitherto generally accepted as distinct species, are shown separately. The true specific value of the arrangement and nature of the papillæ on the proboscis can only be settled by the examination of numerous individuals from various localities; in the meantime it appears best to consider Annelids differing in these particulars as at least varieties worthy of a name.

Eulalia viridis, O. F. Müller. McIntosh, Mon. Brit. Ann., vol. ii., p. 55 .

The variety of $E$. viridis, most commonly found at Torquay, is coloured an uniform dark green, the cirri being rather lighter in colour. It is particularly abundant where the limestone rocks have been much eaten away from about half-tide mark downwards. It appears to like crawling about the damp rocks out of the water when the tide is low, and does not hesitate to leave the water when placed in a shallow vessel. The terminal papillæ of the proboscis numbered fourteen in all the individuals examined, like those found by de St. Joseph at Dinard; but the whole of the extended proboscis was covered with papillæ.

The variety ornata of de St. Joseph is fairly common, but does not appear to extend above the Laminarian zone. There appears to be very little doubt that this is the P. griffithsii of Johnstone. His specimens were obtained from Torbay, and there does not appear to be any species of Eulalia found there to which the description could apply. 
The number of segments per inch of length mentioned by Johnstone applies much better to ornata than to $E$. nebulosa, Montagu.

The variety aurea of Gravier is also found at Torquay in the same localities as ornata. The dorsal cirri are distinctly less pointed, and the breadth of the segments greater in proportion to the length than in the case of the other varieties.

Eulalia nebulosa, Montagu $=E$. punctifer $a$, Grube. McIntosh, Mon . Brit. Ann., vol. ii., p. 53.

One specimen only from Corbyn's Head. Colour dull green rather than yellowish or red; some of the dorsal cirri heavily marked with dark colouring matter. The much longer upper limb of the bifid. setigerous process of the foot is very characteristic of this species.

Eumida sanguinea, Ersted=E. pallida, Grube. McIntosh, Mon. Brit. Ann., vol. ii., p. 66.

The real distinction between the genera Eulalia and Eumida, as defined by Malmgren and McIntosh, is that in Eulalia the first pair of tentacular cirri are attached to a segment divided from the head by a constriction visible at least on the ventral side, while in Eumida the first pair of tentacular cirri are apparently attached to the head, the first segment being soldered to the head. Such a distinction is, however, unsatisfactory, because the visibility of a dividing line between the segment and head depends so much on the method of preparation of the specimen. The only British species is, however, easily recognised as a rule by the peculiar white markings, which look as if they had been painted on with Chinese white. It is common amongst the Laminaria roots at Torquay. Most of the specimens are coloured a pale brown, but one or two were found with a decided red tinge in the posterior part of the body.

The proboscis is covered with very small papillæ, which almost or entirely disappear in preparations, for which reason the smoothness of the proboscis as a generic distinction is also objectionable. Some of the individuals had black patches in the intestines like those described by Gravier in his Eumida communis. Bull. Sc. Fr. Belg., t. xxxix., p. 18.

Phyllodoce Maculata, Johnstone. McIntosh, Mon. Brit. Ann., vol. ii., p. 89.

This is the only species of Phyllodoce which is at all common between tide marks at Torquay. It is found amongst rocks and weeds, and also in the sand. On one occasion sixteen individuals were found 
in a whelk shell containing the decaying remains of a hermit crab.

The Torquay species agree well with the beautiful coloured drawing given in the Mon. Brit: Ann.

One specimen was found in a limestone pool which differed considerably from the type : the general colour much greener, the dorsal cirri larger in proportion and without spots, the distance between the feet greater. The number of the rows of papillæ on the proboscis could not be observed. Possibly this is the Phyllodoce maculata of Ersted.

Phyllodoce lamelligera, Gmelin. McIntosh, Mon. Brit. Ann., vol. ii., p. 76 .

One light-coloured individual under a stone at Hope's Nose, and another of the normal colouring at Meadfoot.

Papillæ of the proboscis could not be observed.

Phyllodoce Paretti, De Blainville. McIntosh, Mon. Brit. Ann., vol. ii., p. 76.

The head and about twenty segments of one from Corbyn's Head. The specimen, mounted in weak Formalin solution, retained its beautiful colouring for some weeks, then changed gradually to a reddish brown.

Gosse, in The Aquarium, second edition, p. 243, describes an example of this species from Torbay.

Eteone PICta, De Quatrefages. McIntosh, Mon. Brit. Ann., p. 100.

Small ones, about $25 \mathrm{~mm}$. in length, are not uncommon amongst Laminaria roots. The pattern of the colouring agrees with that described by McIntosh, but the anal cirri are quite differently shaped to those in Pl. XLV, Fig. 3, of the Monograph, being ovate, exactly like those figured by Gravier, Bull. Sc. Fr. Belg., Pl. xvi, Fig. 14.

Notophyllum foliosum, Sars = alatum, Langerhans. McIntosh, Mon. Brit. Ann.

One from Livermead. The dorsal cirri appear to be much more deciduous than the ventral. Colouring like that described by McIntosh for specimens kept some time in confinement, namely, brownish green without the red iridescence.

\section{Nepthydidæ.}

Nepthys Hombergir, Lamark. McIntosh, Mon. Brit. Ann., p. 17.

Moderate-sized examples of this species, about $90 \mathrm{~mm}$. in length, are common in the sand at Tor Abbey Sands and Livermead. They were 
also found in rather dirty, muddy sand in the inner harbour of Torquay. The posterior lamina of the ventral branch of the foot is more pronouncedly directed upwards and more truncate than is shown in any of the figures given in the monograph.

Nepthys cirrosa, Ehlers. McIntosh, Mon. Brit. Ann., vol. ii., p. 36. In clean sand in company with $N$. Hombergii, but not quite so numerous. It may be distinguished at once from $N$. Hombergii by its comparatively narrow width and the light colour of the bristles.

McIntosh says (p. 38) that de St. Joseph distinguishes this species by the larger size of the branchiæ. But it is not the branchiæ themselves, but the "cirre branchial" (called by McIntosh "the dorsal cirrus at the base of the branchia") which de St. Joseph says becomes larger and larger, until, for about the thirty last segments, it is almost longer than the branchiæ. See Ann. Sc. Nat., Sth series, xvii., p. 21.

\section{Hesionidæ.}

Castalia Fusca, Johnston=Kefersteinia cirrata, Kef. McIntosh, Mon. Brit. Ann., vol. ii., p. 127.

Common under stones, especially at Meadfoot; also in Laminaria roots. It is an extremely brittle species which, like other very brittle annelids, is best lifted up with a soft camel-hair brush.

Magalia peramata, Mar. and Bobr. McIntosh, Mon. Brit. Ann., vol. ii., p. 136.

Common amongst Laminaria roots.

\section{Nereidæ.}

Micronereis variegata, Clpd. Claparede, Beob. über anat. wirbel thiere, etc., 1863, p. 57 and Pl. XI, Figs. 56-7; and Glanures parmi les Ann. de Port Vendres, p. 122, Pl. xII, Fig. 4a.

This little aberrant member of the Nereidæ is not recorded in the "Fauna of Plymouth." Four or five individuals were found amongst red algæ and Lithothamnion from the rocks between Oddicombe and Babbicombe beaches.

The length is $4 \mathrm{~mm}$., number of segments 21 . The head, which is rounded in front, has no tentacles or palps. There are four eyes, the lateral pair close together, the posterior pair close to the margin of the head; the first pair have conspicuous crystalline lenses. There are four pairs of tentacular cirri, the front pairs situated on the front edge of the buccal segment low down; the posterior pairs, which are inserted higher up, are slightly longer than the other. The tentacular cirri are 
fusiform and are tinged with yellow. The body is coloured purple. The jaws are about twice as long as broad, the number of teeth in each jaw five. There are no denticles. The first pair of feet, which are uniramous, are attached to the buccal segment. The second pair are also uniramous, but all the other feet are deeply bifid.

There are about twenty bristles in each foot, the terminal pieces of which are straight and narrow; they are much longer in proportion to their length than those shown in Claparède's drawing. Bristles and spines are colourless. The drawing given by Claparède is quite accurate for an individual drawn under compression, but the feet and cirri as shown there are much flattened out.

Leptonereis Vaillanti. de St. Joseph, Ann. des Sc. Nat. Zool., vol. v., 1888, p. 246.

One imperfect male Heteronereid form of this species was found in the month of February at Oddicombe. The posterior of the three regions into which the body is divided was absent, but the remaining segments agreed with the description and figures given by de St. Joseph. It is not recorded in the "Fauna of Plymouth."

Nereilepas fucata, Savigny. McIntosh, Mon. Brit. Ann., vol. ii., Pl. LXI, Figs. 6 and $6 a$.

This is not strictly a littoral species, but may be sometimes found in whelk shells thrown up on the shore. One lived for about six months in a small aquarium in a broken whelk shell, but without any hermit crab. It usually had the head and about ten or twelve segments of the body protruding from the shell; this part of the body being curved and continually waved backwards and forwards, giving the worm a most curious resemblance to a cobra.

Nereis pelagica, L. McIntosh, Mon. Brit. Ann., vol. ii., Pl. LX, Figs. 6 and 6 a.

This Nereis is extremely common in the roots of the Laminaria, nearly every root containing one or two. Several of the Heteronereid form were found in the same situation in January and February, 1907, on Oddicombe beach. They measured about $30 \mathrm{~mm}$. in length.

Nereis Dumerilit, Aud. and Ed. McIntosh, Mon. Brit. Ann., vol. ii., Pl. LX, Figs. 10 to $10 \mathrm{c}$.

Small individuals, 20 to $30 \mathrm{~mm}$. in length, are very common amongst lagæ from rock pools and the Torquay harbour. 
Nereis irrorata, Mgrn. McIntosh, vol. ii., Pl. L, Fig. 17; and Pl. Lx, Fig. 8.

Occasionally under stones at Petit Tor Bay and Babbicombe beach ; also amongst roots of Zostera at Corbyn's Head.

The glands in the feet are very conspicuous in this species, both when living and preserved.

Nereis Cultrifera, Grube. McIntosh. Mon. Brit. Ann., vol. ii., Pl. LX.

Under stones, not very common, on the edge of the submerged forest at Tor Abbey Sands. 
KEY TO THE GENERA OF PHYLLODOCIDA FOUND ON THE FRENCH AND ENGLISH COASTS

OF THE CHANNEL.

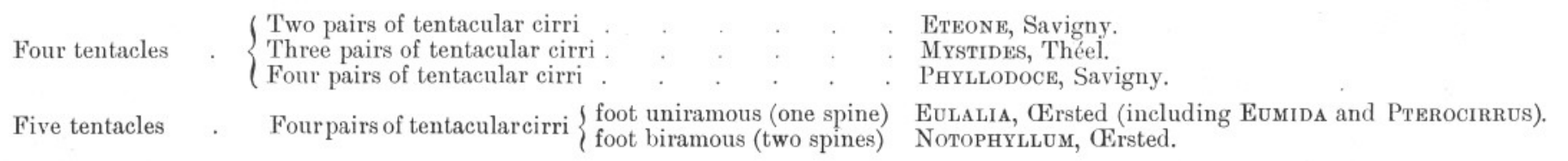

KEY TO THE SPECIES OF PHYLLODOCIDE FOUND ON THE FRENCH AND ENGLISH COASTS

OF THE CHANNEL.

\section{Genus Eteone.}

$\begin{gathered}\text { Head as broad or broader } \\ \text { than long }\end{gathered}$
Head longer than broad
or brown . . . . . Dorsal cirri obliquely ovate. Length, $40 \mathrm{~mm}$.

\section{Genus Mrstides.}

One pair of tentacular cirri on each of the first three segments. Length, $20 \mathrm{~mm}$.

A pair of tentacular cirri on the first segment, two pair on the second segment, the posterior pair with a leaf-like appendage. Length, $10 \mathrm{~mm}$.

* Not recorded from the British area.

(Protomystides) * bidentata, Lang. (Mesomistides) * limbata, de St. Joseph. 


\section{Genus Phyllodoce.}

Median dorsal cirri $\left\{\begin{array}{c}\text { Colour brown. On each side of the proboscis two rows of large lanceolate } \\ \text { papillæ in anterior part, and three rows of small papillæ at the base. }\end{array}\right\}$ suborbicular Terminal papillæ, 20 .

* macropapillosa, de St. Joseph.

Colour greenish yellow with a brown spot formed of transverse papillæ on lines on each segment, and usually a spot on each dorsal cirrus. base of proWidth of body without feet, $1 \mathrm{~mm}$. Length, $80 \mathrm{~mm}$. Terminal boscis

papillæ, 17

\section{Four rows of maculata, Ersted $=$}

Median dorsal cirri subrectangular

Dorsal cirri greyish green, each segment marked with blue and brown transverse lines. Ventral cirri with a nipple-like tip. Proboscis with six rows of tuber- $($ groenlandica, Ersted= cles on front part of proboscis and six rows of papillæ on each side of base. $\{$ mucosa, Malmgren. Terminal papillæ, 17. Width of body without feet, $3 \mathrm{~mm}$. Length, $180 \mathrm{~mm}$.

Colour reddish, with three dark spots on each segment. Six rows of papillæ on each side of proboscis at base. Terminal papillæ, 16. Width, 1.5 mm. * pulchella, Malmgren. Length, $30 \mathrm{~mm}$. Tentacles and tentacular cirri fusiform. Dorsal cirri bright yellow

Paretti, De Blainvill $=$

Longest tentacular cirri

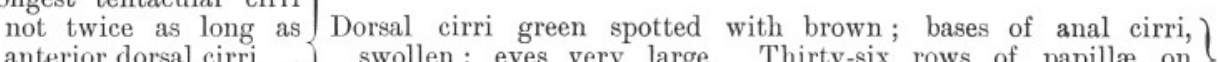
anterior dorsal cir. splendens, de St. Joseph.

Median

dorsal cirri cordate or elongate

ovate.

Longest tentacular cirri several times longer than the anterior dersal cirri

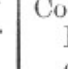
$\left.\begin{array}{l}\text { swollen; eyes very large. Thirty-six rows of papillæ on } \\ \text { proboscis. Width, } 1 \mathrm{~mm} \text {. Length, } 30 \mathrm{~mm} \text {. }\end{array}\right\}$

Dorsal cirri red. Base of proboscis covered with papillæ. Terminal papillæ, 8. Width, $1 \mathrm{~mm}$. Length, 15 to $100 \mathrm{~mm}$. . Ter- $\}$ rubiginosa, de St. Joseph.

* macropthalma, Schmarda.

Dorsal cirri, dull green ; body, iridescent Base of proboscis ) blue or green. Width without feet, 3 to with six rows of pa$4 \mathrm{~mm}$. Length, 160 to $750 \mathrm{~mm}$. . . pillæ on each side

lamelligera, Gmelin. Base covered with ? papillæ

var. laminosa, Savigny.

骂

운

声 cles, then six rows of large papillæ, each row of three large papillæ followed by numerous rows of small papillæ. Terminal

* papulosa, de St. Joseph.

papillæ, 16. Width, $4 \mathrm{~mm}$. Length, $300 \mathrm{~mm}$.

* Not recorded from the British area. 


\section{Genus Eulalia.}

Ventral cirri of the second pair of tentacular cirri forming a long lanceolatefoliaceous process $=$ subgenus Pterocirrus.

Dorsal cirri lanceolate tapering to

a point.
Brown or dull green. Terminal papillæ, 48. Length, $50 \mathrm{~mm}$.

Pinkish grey. Terminal papillæ, 24. Length, $7 \mathrm{~mm}$. macroceros, Grube.

* limbata, Clpd.

viridis, var. ornata, de St.

Ventral cirri of second pair of tentacular cirri not foliaceous
* parva, de St. Joseph.

viridis, L. Joseph.

Green with a brown spot on each segment except the first. Proboscis without lateral papillæ. Terminal papillæ, 8. Length, Green. Terminal papillæ, 14 to 21 . Length, $80 \mathrm{~mm}$.

Yellow, with a dark spot on the middle of each segment and two parallel bars on each side of the segment. Terminal papillæ, 18. Length, $60 \mathrm{~mm}$. . . . .

Yellow, with two longitudinal violet lines on each side of the central line, and a dark line on each side of the segment. Terminal papillæ, 20. Length, $80 \mathrm{~mm}$.

viridis, var. aurea, Gravier.

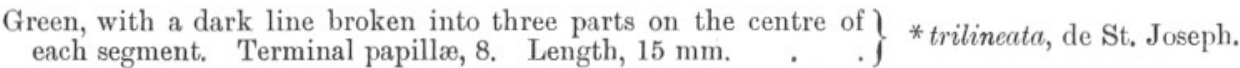

First and second segments uniform brown, remaining segments

spotted. Unpaired tentacle half-way between the eyes and part * venusta, de St. Joseph.

of head. Terminal papillæ, 14 . Length, $30 \mathrm{~mm}$.

* Not recorded from the British area. 


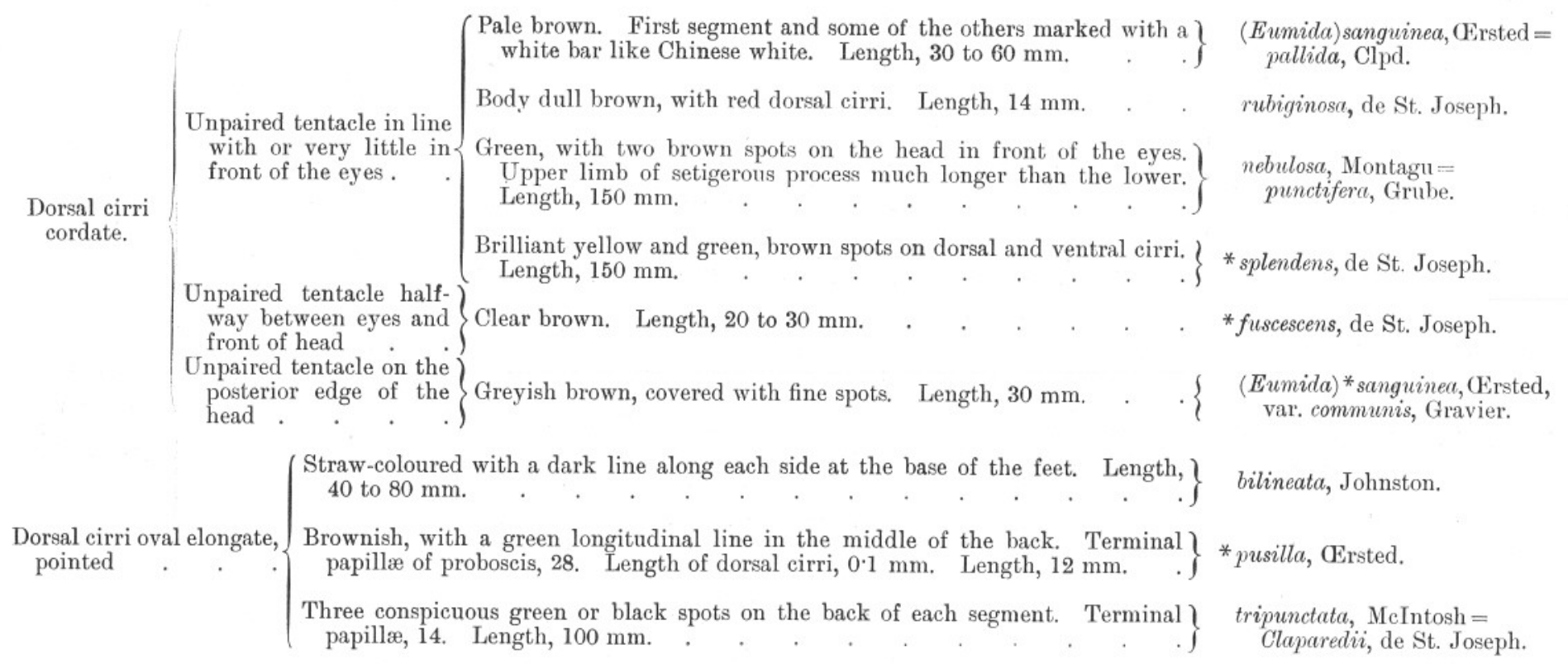

\section{Genus Notophyllum.}

Head furnished posteriorly with a flap on each side. Dorsal cirri uniform

foliosum, Sars=alatum, Langh.

* Not recorded from the British area. 


\section{KEY TO THE NEREID $A$ OF THE FRENCH AND ENGLISH COASTS OF THE CHANNEL.}

No denticles (Buccal segment with feet and bristles. No palps or tentacles. Bristles all of one kind. ) (paragnaths) Length, 4 to $6 \mathrm{~mm}$. . . . . on $\quad$ Buccal segment without feet. Head rounded; conspicuous glands in feet. More than

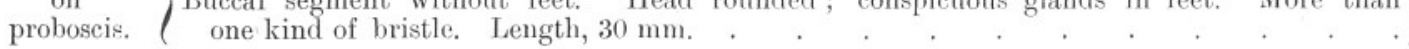
Micronereis variegata, Clpd. Leptonereis Vaillanti, de St. Joseph.

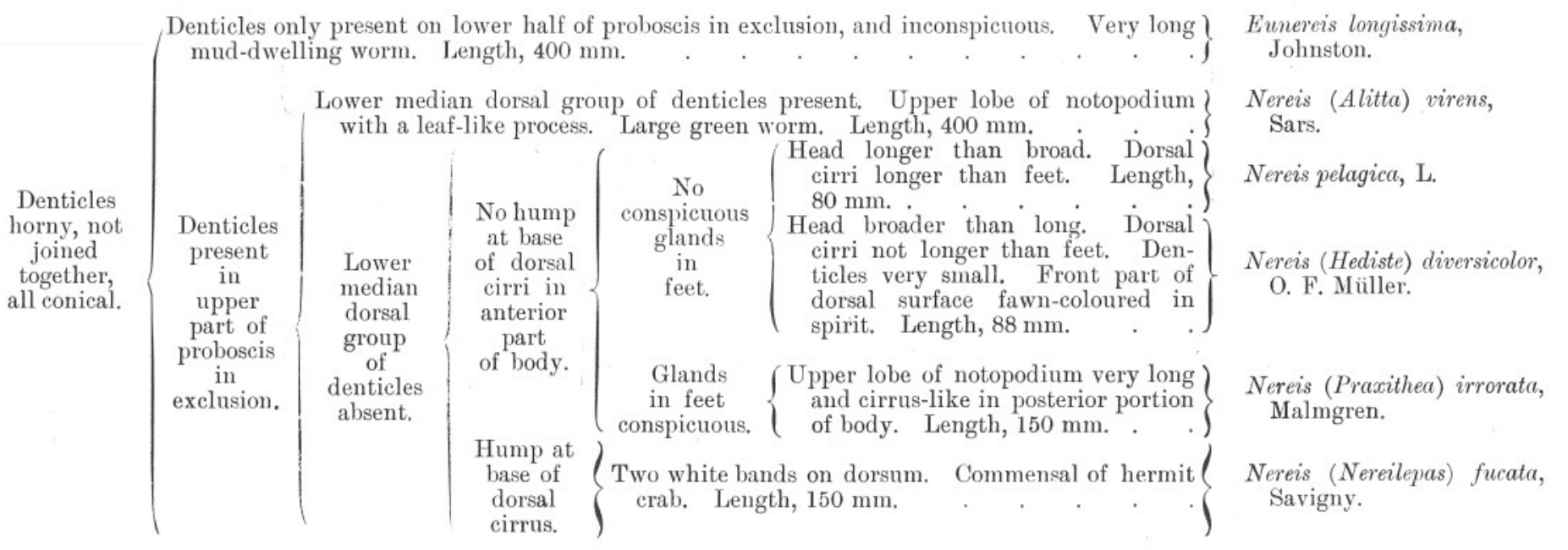


KEY TO THE NEREIDA OF THE FRENCH AND ENGLISH COASTS OF THE CHANNEL-continued.

Denticles horny, in some

groups at least very Tentacular cirri very long, reaching fifteenth segment

small, very close to- Conspicuous glands in notopodium; body often spotted with purple. Length, 20 to $\}$ Nereis J umerilli, Aud. and Ed. gether, and arranged in $\quad 70 \mathrm{~mm}$.

comb-like rows

Note.--The main divisions of this key are taken from the table given by Baron de St. Joseph, Ann. des Sc. Nat. Zool., series 8 T. v., 1898 . 